\title{
Geological And Geotechnical Characterization Of The Beni Moussa Perimeter In The Tadla Plain(Morocco)
}

\author{
Kharmouch Achraf, Phd \\ Sultan Moulay Slimane University, Faculty Of Sciences And Techniques, \\ Department Of Earth Sciences, Beni Mellal,Morocco \\ Najine Abdessamad, Professor \\ Sultan Moulay Slimane University, Faculty Of Sciences And Techniques, \\ Department Of Earth Sciences, Beni Mellal, Morocco \\ Wafik Amina, Professor \\ Cadi Ayyad University, Faculty Of Sciences Semlalia, Department Of \\ Geology, Marrakech, Morocco
}

Doi:10.19044/esj.2020.v16n27p204 URL:http://dx.doi.org/10.19044/esj.2020.v16n27p204

\begin{abstract}
The Beni Moussa perimeter in the plain of Tadla is located in the Beni Mellal - Khenifra region characterized by the diversity of its relief where the mountain meets the plain through the foothills. Bibliographic studies raise the dominance of limestone formations in the Atlas ranges of this region, and the piedmont accumulates alluvium deposited by rivers, while the plain is filled with mio-plio-quaternary deposits. A series of seven drill holes of various depths, supplemented by pressuremeter measurements every $1.50 \mathrm{~m}$ of depth using the Menard pressuremeter, was carried out on sites scattered around the perimeter of the Beni Moussa in the plain of Tadla, to validate at first the bibliographic geological models, then to appreciate the bearing capacity of the lithologies revealed. The lithological sections thus revealed an alternation of alluvial deposits, clays and clay loams, deposited on calcareous formations, resulting from the dolomitic and calcareous mountainous debris mobilized following the seasonal temperature's variation of the region. Moreover, the measured pressurometric ranges characterize a generally high bearing capacity, and reflect the generalized overconsolidation of the facies and soils encountered in the Beni Moussa area, except for the Middle Pleistocene formations, which are mainly characterized by channeled conglomeratic deposits.This study's datathus reflect a good bearing capacity of the ground formations, capable of supporting the superstructures founded in this perimeter.
\end{abstract}


Keywords: Beni Mellal, Lithological Section, Menard Pressuremeter Test, Bearing Capacity, Core Drilling

\section{Introduction:}

Morocco presents a diversity of structural domains. Each domain is characterized by certain materials from a certain orogenic phase reflecting its geological history.

In addition, various arrangements of the country's different reliefs can be observed following the various recent tectonic phases, including in particular the Pliocene and Quaternary (Plio-Quaternary) phases, which are directly responsible for the reliefs observed in the different geomorphological domains (Michard, 1976).

The region of Beni Mellal - Khenifra in particular is distinguished by the three distinct topographical units that it shelters: plain, mountain and foothills.

The geology of this region is rich and complex in its diversity. Indeed, two mountainous entities of the Atlas area (the Middle Atlas and the Central High Atlas) are obliquely connected. Wide valleys are carved by rivers, fed and magnified by the abundance of rain and snow during the winter season. This is the case of the wadi of OumEr-Rabiâ, which is fed by about forty springs. Hence the substratum of the majority of the grounds found there is argillaceous silts with calcareous clusters resulting from the alluviums of atlasic origin. (Missante, 1963 ;Massoni et al., 1967 ; Piqué et al., 2015 ; Taibi, El Khalki, \&Hannani, 2015).

This study focuses on a geological and geotechnical reconnaissance of various sites at the Beni Moussa perimeter on the Tadla plain, consisting in obtaining data on the lithological and intrinsic characteristics of the soil.

Indeed, the geological study and geotechnical identification of soils is very important on a global scale and particularly in Morocco. The safety and stability of any planned structure as well as the durability of the built structures depend on a good recognition of the supporting soil. As geotechnics is a relatively young branch compared to the other branches of civil engineering, the present study feeds its database with measurements of soil characteristics in various zones within the above-mentioned perimeter.

It is mainly a question of studying the succession of lithological layers in the areas studied, the evaluation of their geometry, as well as the identification of the geotechnical nature of the soils at the points studied to answer the question relating to the mechanical bearing characteristics of the formations in this region. The main objective of this study is to validate, firstly, the different geological models raised in the bibliography, then to study the bearing capacity of the different lithological sections. 


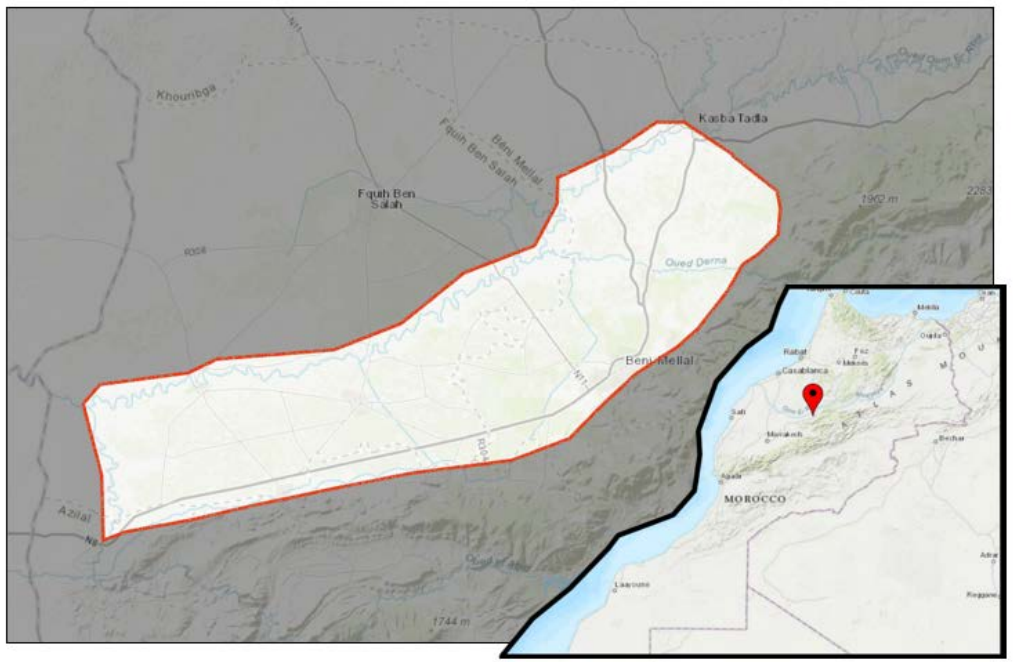

Figure 1. Geographical location of the Beni Moussa area

The Beni Moussa perimeter is located in theBeni Mellal - Khenifra region in Morocco(figure 1).The geographical delimitation of this perimeter, through the extent of its water table, is defined on its northern side by the wadi of OumEr-Rabiâ, by the foot of the Atlas Mountains in the south. In the West the water table is limited by the wadi El Abid, while the artificial line linking Kasba Tadla and GhormLaâlam can define its eastern limit (Etienne \&Guessab, 1975).

According to the geological map of Morocco (Service géologique du Maroc, 1985), the above-mentioned mountainous entities of the Atlas area are predominantly limestone. In fact, the limestone basement at the level of the High Atlas is buried in a thick folded secondary cover. The alpine-style geological component is quite complex and comes essentially from the PontoPliocene phase. Whereas the Dir corresponds to a zone of accumulation of alluvium deposited in the form of an alluvial cone at the outlet of the wadis from the Atlas (Piqué et al., 2015; Taibi, El Khalki, \&Hannani, 2015).

The perimeter of the Beni Moussa of the Tadla plain, the synclinal gutter of the region, is filled with mio-plio-quaternary (figure 2) deposits formed by alternating conglomerates of conglomerates, sandstone and marl and ending in lacustrine deposits (Choubert\& Faure-Muret, 1962 ; Taibi et al., 2015). 

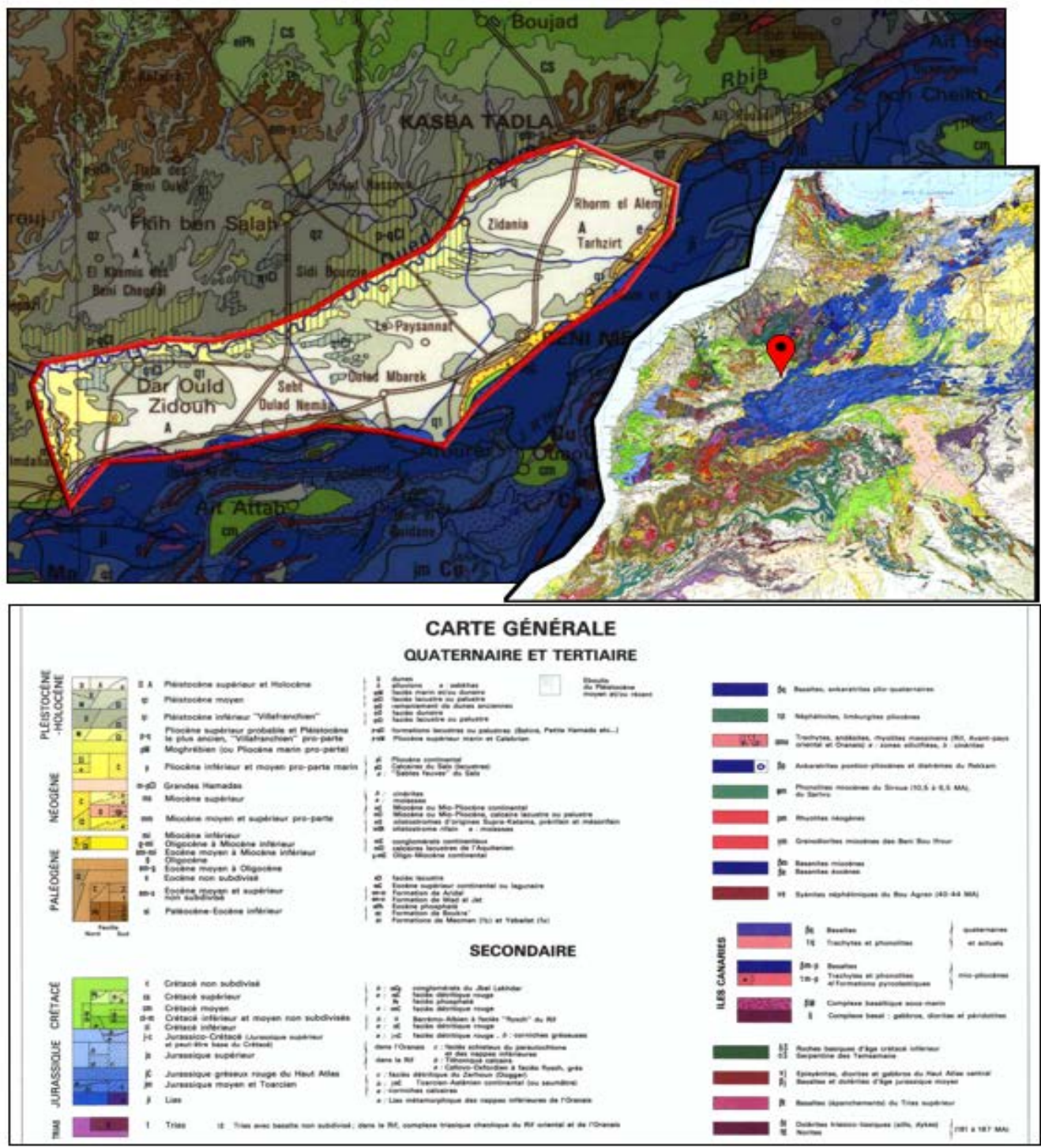

Figure 2. Geological map of the Béni Moussa area (Service géologique du Maroc, 1985)

\section{Materials and methods}

In order to collect the data expected in the present study, a series of core drillings were carried out at various depths in seven sites scattered (Table 1) along the entire length of the Beni Moussa perimeter.

\begin{tabular}{|c|c|c|c|c|c|}
\hline Site Area & $\begin{array}{c}\text { Survey } \\
\text { No. }\end{array}$ & $\mathbf{X}$ & $\mathbf{Y}$ & $\mathbf{Z}$ & $\begin{array}{c}\text { Survey } \\
\text { depth }\end{array}$ \\
\hline $\begin{array}{c}\text { Ouled Saïd El } \\
\text { Oued }\end{array}$ & S1 & $408.711,942$ & $219.964,271$ & $475 \mathrm{~m}$ & $20 \mathrm{~m}$ \\
\hline Ouled Abdellah & S2 & $401.784,201$ & $212.849,253$ & $457 \mathrm{~m}$ & $30 \mathrm{~m}$ \\
\hline Ouled Yaïch & S3 & $412.739,180$ & $205.581,712$ & $515 \mathrm{~m}$ & $25 \mathrm{~m}$ \\
\hline Ouled Moussa & S4 & $399.821,436$ & $187.728,051$ & $469 \mathrm{~m}$ & $50 \mathrm{~m}$ \\
\hline
\end{tabular}




\begin{tabular}{|c|c|c|c|c|c|}
\hline Sidi Aissa & S5 & $378.364,931$ & $195.631,142$ & $403 \mathrm{~m}$ & $30 \mathrm{~m}$ \\
\hline $\begin{array}{c}\text { Souk Sebt Ouled } \\
\text { Nemma }\end{array}$ & S6 & $377.447,907$ & $191.275,655$ & $410 \mathrm{~m}$ & $40 \mathrm{~m}$ \\
\hline Tarmast & S7 & $346.832,090$ & $190.127,130$ & $361 \mathrm{~m}$ & $30 \mathrm{~m}$ \\
\hline
\end{tabular}

Table 1. Sites of core drillings (Lambert coordinates North Morocco zone)

Figure 3. Location of core drill holes on the Beni Moussa geological map

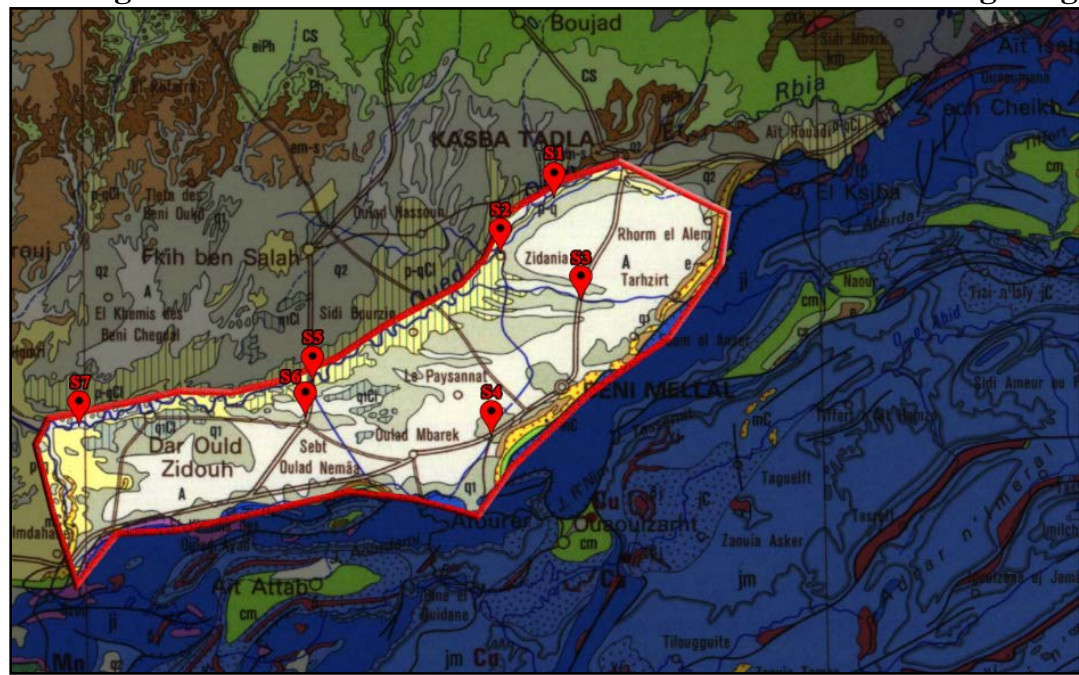

In addition, and in order to get an idea of the bearing capacities of the different substrates, pressuremeter tests were carried out every $1.5 \mathrm{~m}$ at these soundings using a pressuremeter (figure 4).

The Menard pressuremeter test consists of radially expanding a threecellular cylindrical probe placed in the ground, measuring and recording the pressures applied by the probe and the variations in volume of the latter in order to determine the relationship between the pressure applied and the expansion of the probe (Association Française de Normalisation [AFNOR], 2015). This test can be applied in natural soil, in indurated soil and soft rocks, or in treated or untreated embankments, both on land and in water.

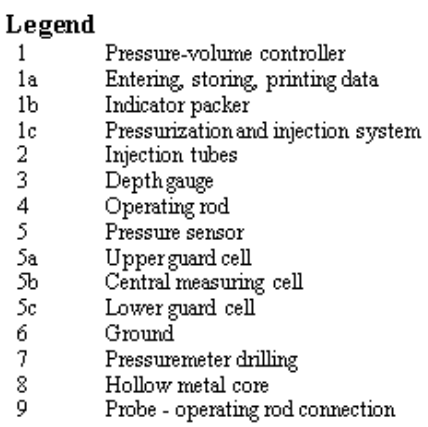




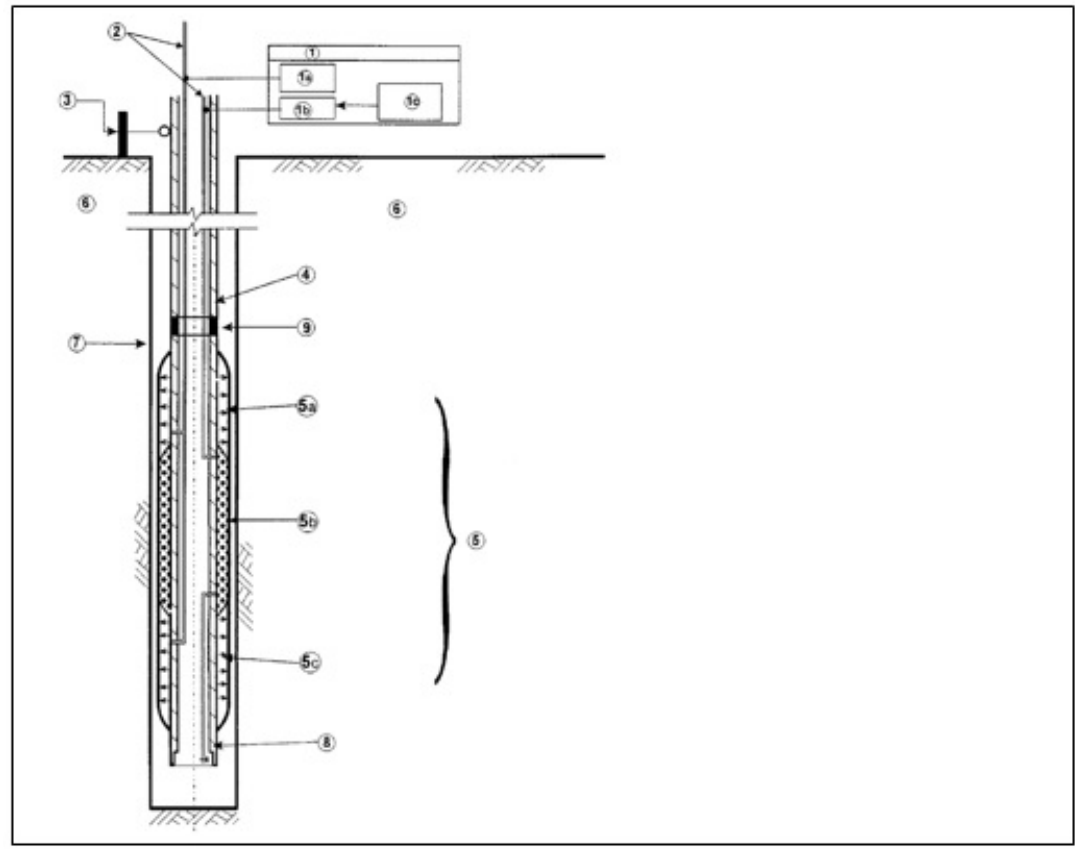

Figure 4. Pressuremeter diagram (AFNOR, 2015)

It should be noted that the usual ranges (Segelm, 1998) of Menard $\mathrm{E}_{M}$ and pı pressure gauge characteristics make it possible to characterize the main soils encountered (tableau 2).

\begin{tabular}{|c|c|c|}
\hline Formation & $\mathbf{E}_{\mathbf{M}}$ (MPa) & pı (MPa) \\
\hline Vases and Peat & 0,2 to 1,5 & 0,015 to 0,02 \\
\hline Soft clays & 0,5 to 3,0 & 0,05 to 0,30 \\
\hline Plastic clays & 3,0 to 8,0 & 0,30 to 0,80 \\
\hline Stiff clays & 8,0 to 40,0 & 0,60 to 2,00 \\
\hline Marl & 5,0 to 60,0 & 0,60 to 4,00 \\
\hline Muddy sands & 0,5 to 2,0 & 0,10 to 0,50 \\
\hline Silts & 2,0 to 10,0 & 0,20 to 1,50 \\
\hline Sand and gravel & 8,0 to 40,0 & 1,20 to 5,00 \\
\hline Sedimentary sands & 7,5 to 40,0 & 1,00 to 5,00 \\
\hline Recent backfill & 0,5 to 5,0 & 0,05 to 0,30 \\
\hline Old backfills & 4,0 to 15,0 & 0,40 to 1,00 \\
\hline
\end{tabular}

Table 2. Ususal values of EMand pl

The methodological approach followed for each of the seven sites studied in the Beni Moussa perimeter can be briefly described in the flowchart in figure 5 below : 


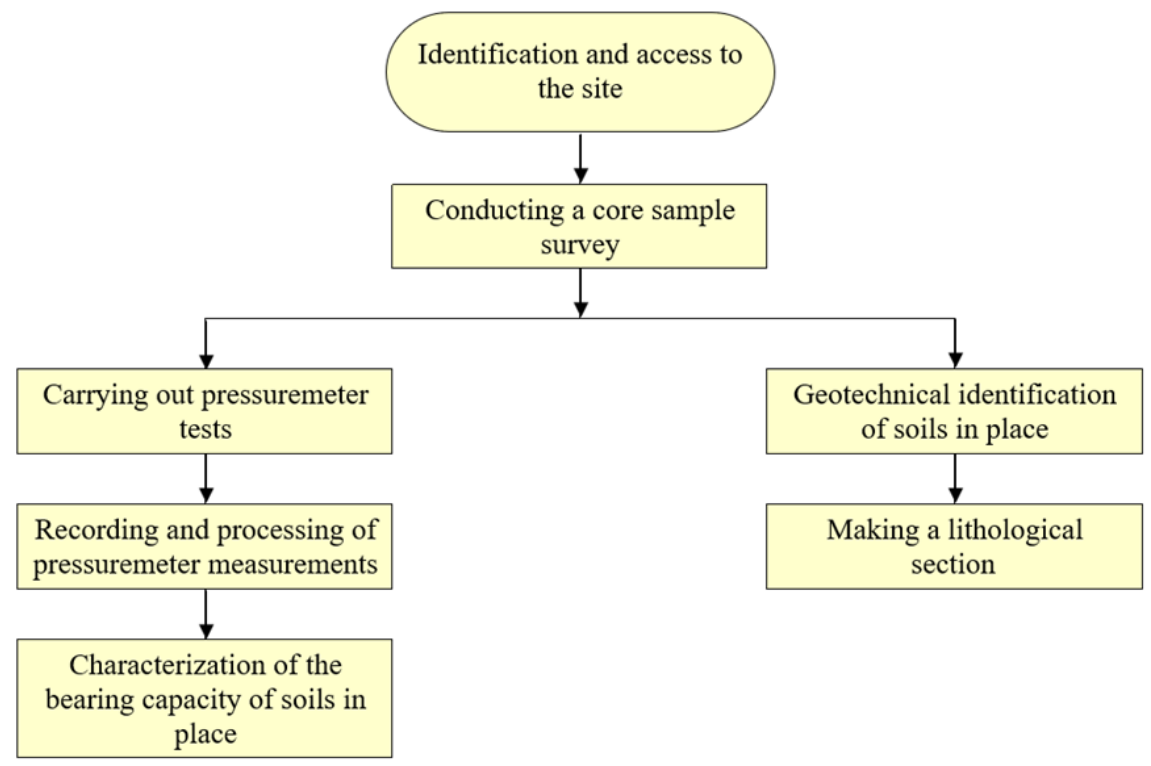

Figure 5. Organisation chart of the approach followed in each studied site

\section{Results and discussion}

The core samples taken at the study sites show that the lithological successions are more or less diversified (Table 3 and Table 4). The lithological sections generally show an alternation of alluvial deposits, clays and clayey silts deposited on calcareous formations.

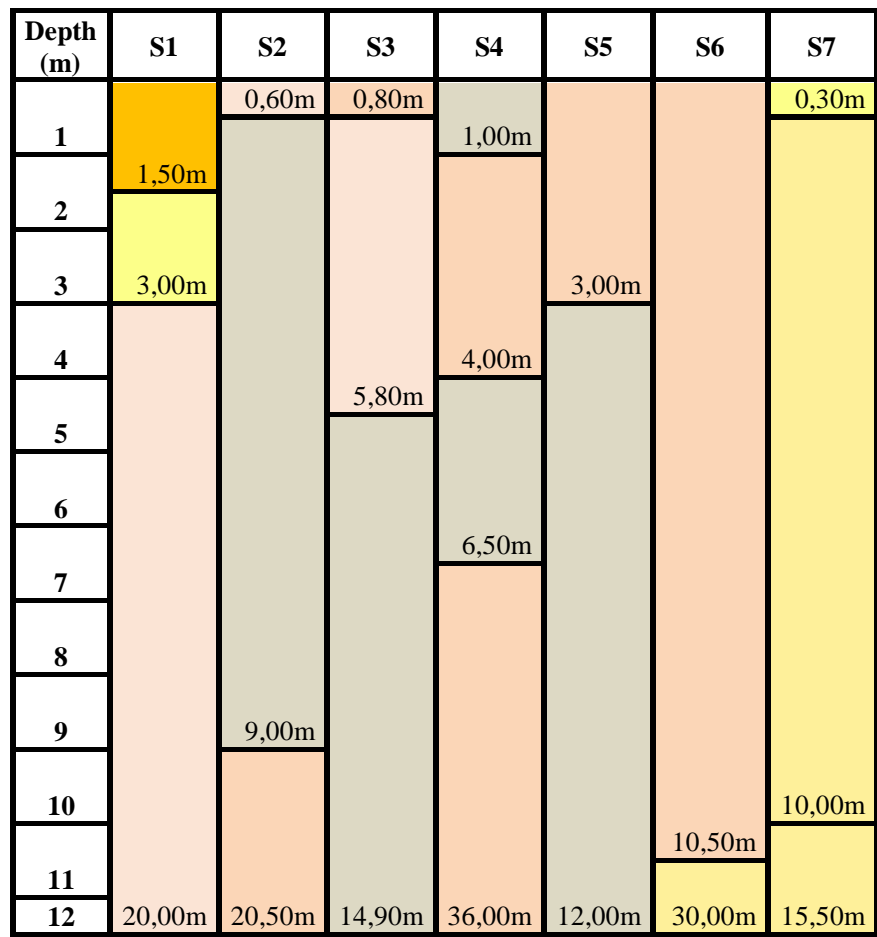




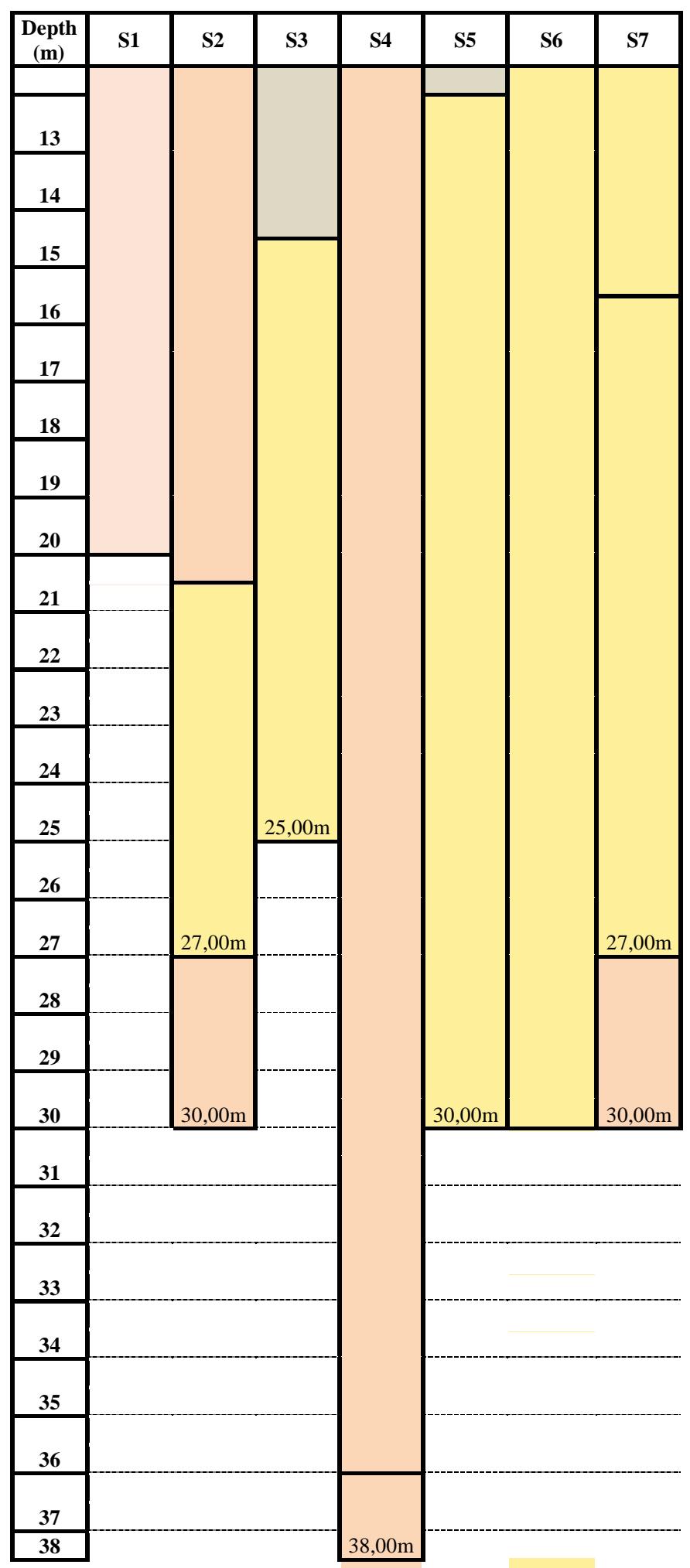




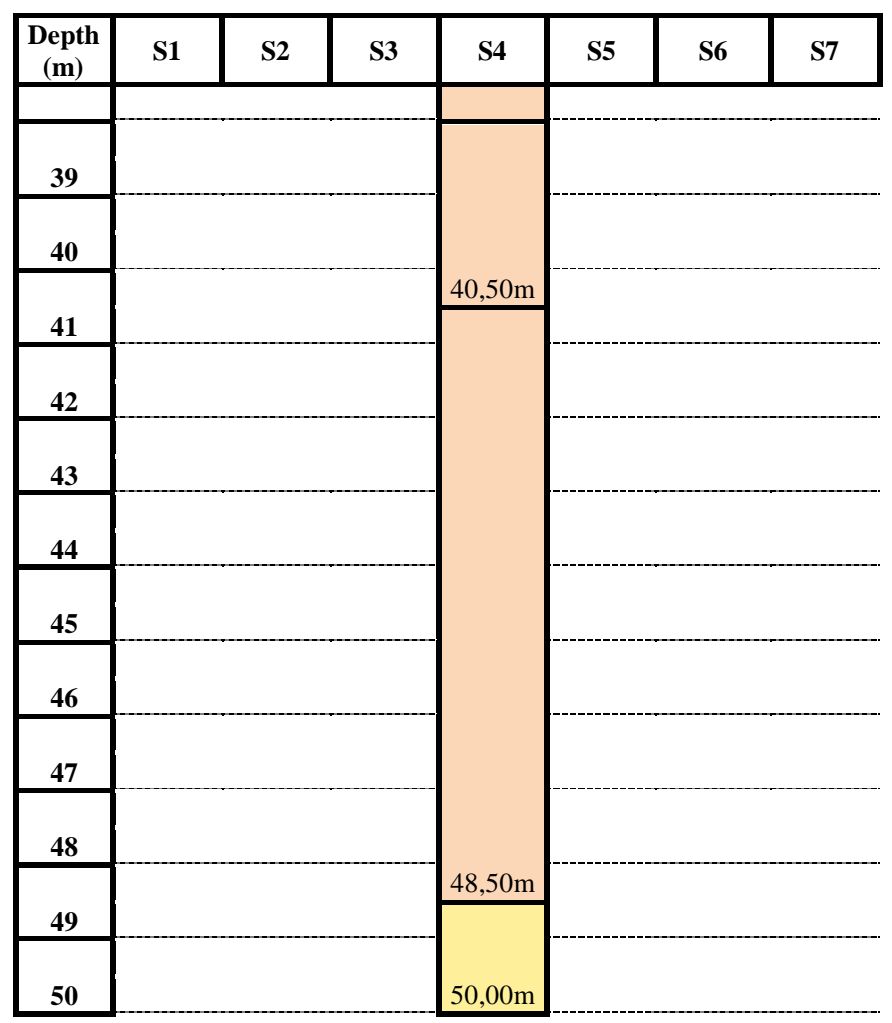

Table 3. Lithological Sections of the cored holes

\begin{tabular}{|c|c|c|}
\hline \multirow{3}{*}{ S1 } & & Brownish sandy loam \\
\cline { 2 - 3 } & & Alluvium with a sand-lime matrix \\
\cline { 2 - 3 } & & $\begin{array}{c}\text { Reddish to whitish gravelly clayey silt in } \\
\text { places }\end{array}$ \\
\hline
\end{tabular}

\begin{tabular}{|c|c|c|}
\hline \multirow{4}{*}{ S2 } & & Clay loam \\
\cline { 2 - 3 } & & Wadi alluvium with a sandy matrix \\
\cline { 2 - 3 } & & $\begin{array}{c}\text { Over-consolidated argillite with intercalations } \\
\text { of over-consolidated siltite }\end{array}$ \\
\cline { 2 - 3 } & & $\begin{array}{c}\text { Over-consolidated sandstone marl-limestone } \\
\text { traces of whitish marl-limestone }\end{array}$ \\
\hline
\end{tabular}

\begin{tabular}{|c|c|c|}
\hline \multirow{4}{*}{ S3 } & & Silty, gravelly, brownish clay \\
\cline { 2 - 3 } & & Slightly sandy clayey silt \\
\cline { 2 - 3 } & & $\begin{array}{c}\text { Alluvium with calcareous, sandstone and } \\
\text { quartz elements, cemented by a sandy-clay } \\
\text { matrix }\end{array}$ \\
\cline { 2 - 3 } & & $\begin{array}{c}\text { Indurated pinkish limestone with unfilled or } \\
\text { clay-filled joints }\end{array}$ \\
\hline
\end{tabular}

\begin{tabular}{|c|c|c|}
\hline \multirow{4}{*}{ S4 } & & $\begin{array}{c}\text { Alluvial gravel with brownish tuffaceous clay } \\
\text { matrix }\end{array}$ \\
\cline { 2 - 3 } & & Reddish silty clay \\
\cline { 2 - 3 } & & $\begin{array}{c}\text { Alluvial gravel with brownish tuffaceous clay } \\
\text { matrix }\end{array}$ \\
\cline { 2 - 3 } & & Reddish clay with tuffed nodules \\
\hline
\end{tabular}




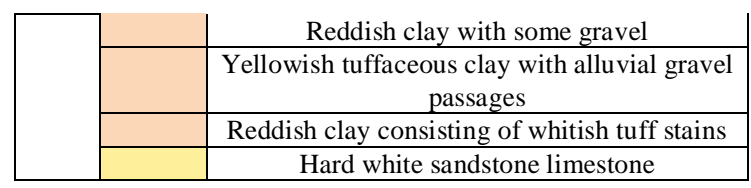

\begin{tabular}{|c|c|c|}
\hline \multirow{3}{*}{ S5 } & & Clay \\
\cline { 2 - 3 } & & Wadi Alluvium \\
\cline { 2 - 3 } & & Rock \\
\hline
\end{tabular}

\begin{tabular}{|c|c|c|}
\hline \multirow{2}{*}{ S6 } & & Blackish Clay \\
\cline { 2 - 3 } & & Limestone rock \\
\hline
\end{tabular}

\begin{tabular}{|c|c|c|}
\hline \multirow{4}{*}{ S7 } & & Silty sand \\
\cline { 2 - 3 } & & Lake limestone \\
\cline { 2 - 3 } & & Marly limestone \\
\cline { 2 - 3 } & & Fractured marl limestone \\
\cline { 2 - 3 } & & Marl Clay \\
\hline
\end{tabular}

Table 4.Identification of soils in the lithological sections

According to the Geological Service of Morocco (1985), the Quaternary constitutes the major part of the studied area. Its morphological evolution depended mainly on the climatic conditions of the region. Indeed, during the winter seasons, the rocks disintegrated under the effect of increased frost wedging, and their debris was transported through the mountain slopes by seasonal waters from snow melting and thawing. It is noteworthy that the vegetation, weakened and dispersed by the cold climate, allowed this evolution. The clastic debris transported in this way accumulated at the foot of the slopes, and the alluvium from the wadis became interstratified at the level of the slope deposits, particularly after the weakening of seasonal flows.

In addition, and during less cold seasons, soil loosening becomes less likely, giving rise to a stabilization of the slopes, especially after the densification of the vegetation. These seasons thus allow pedogenesis.

The analysis of the lithological materials from previous test pits allows the validation of this schematization. Indeed, dolomitic and calcareous rocks, which are frosty, are likely to provide abundant debris. We can thus observe at the level of the High and Middle Atlas rocky ridges marked by the phenomenon of frost (Beaudet, Maurer, \&Ruellan, 1976), while the feet of the slopes are drowned in the colluvial deposits connected to the alluvium of the wadis, relatively sorted. The different lithological sections therefore show mainly lacustrine formations and facies, dating from the Upper Pliocene.

The results (table 5) of the pressuremeter tests carried out during the drilling each $1.50 \mathrm{~m}$ deep made it possible to evaluate the mechanical characteristics. 


\begin{tabular}{|c|c|c|c|c|c|c|c|c|c|c|c|c|c|c|}
\hline \multirow{2}{*}{$\begin{array}{c}\text { Depth } \\
\text { (m) }\end{array}$} & \multicolumn{2}{|c|}{ S1 } & \multicolumn{2}{|c|}{ S2 } & \multicolumn{2}{|c|}{ S3 } & \multicolumn{2}{|c|}{ S4 } & \multicolumn{2}{|c|}{ S5 } & \multicolumn{2}{|c|}{ S6 } & \multicolumn{2}{|c|}{ S7 } \\
\hline & pl(MPa) & Ем(МРa) & pl(MPa) & Ем(МРa) & pl(MPa) & Ем(МРa) & pi(MPa) & Ем(MPa) & pi(MPa) & Ем(MPa) & pl(MPa) & Ем(МРa) & pl(MPa) & $\begin{array}{c}\text { Ем(M } \\
\text { Pa) }\end{array}$ \\
\hline 1,5 & 1,41 & 18,9 & 0,85 & 4,6 & 0,81 & 11,9 & 1,69 & 6,6 & 0,3 & 7,0 & 0,30 & 8,0 & 4,58 & 127,3 \\
\hline 3,0 & 1,27 & 17,3 & 2,01 & 24,8 & 0,90 & 20,1 & 1,51 & 7,8 & 0,3 & 7,0 & 0,40 & 3,0 & 4,65 & 544,9 \\
\hline 4,5 & 1,63 & 27,2 & 2,43 & 36,6 & 0,92 & 19,3 & 2,01 & 9,6 & 0,45 & 6,0 & 0,40 & 4,0 & 4,65 & 359,4 \\
\hline 6,0 & 1,97 & 30,0 & 2,62 & 38,8 & 5,04 & 89,1 & 3,70 & 38,6 & 0,6 & 8,0 & 0,80 & 5,0 & 4,65 & 350,8 \\
\hline 7,5 & 1,12 & 14,9 & 3,31 & 54,0 & 1,45 & 18,1 & 3,52 & 36,8 & 0,7 & 9,0 & 0,90 & 5,0 & 4,65 & 349,0 \\
\hline 9,0 & 1,66 & 55,3 & 5,09 & 94,1 & 2,32 & 20,9 & 3,00 & 24,8 & 0,8 & 10,0 & 1,20 & 5,0 & 4,65 & 349,7 \\
\hline 10,5 & 2,00 & 43,3 & 4,66 & 121,4 & 4,39 & 79,6 & 2,65 & 15,6 & 1,0 & 14,0 & 1,60 & 9,0 & 4,65 & 353,0 \\
\hline 12,0 & 4,38 & 41,3 & 7,84 & 136,7 & 6,43 & 181,3 & 2,98 & 16,8 & 1,0 & 14,0 & 1,90 & 9,0 & 4,65 & 120,3 \\
\hline 13,5 & 4,06 & 75,4 & 5,05 & 100,6 & 8,51 & 231,2 & 1,95 & 10,2 & 2,8 & 18,0 & 2,00 & 10,0 & 4,65 & 90,6 \\
\hline 15,0 & 3,73 & 55,9 & 4,28 & 87,6 & 8,54 & 243,9 & 3,98 & 36,4 & 3,8 & 28,0 & 2,20 & 11,0 & 3,81 & 77,5 \\
\hline 16,5 & 3,76 & 74,7 & 5,08 & 97,0 & 8,52 & 267,8 & 4,31 & 32,8 & 3,6 & 39,0 & 2,50 & 13,0 & 4,65 & 112,5 \\
\hline 18,0 & 5,79 & 97,2 & 5,89 & 126,7 & 2,73 & 50,5 & 2,94 & 17,5 & 4,0 & 45,0 & 2,90 & 14,0 & 4,14 & 112,2 \\
\hline 19,5 & 5,80 & 97,2 & 6,14 & 141,1 & 8,54 & 265,0 & 5,31 & 30,4 & 5,1 & 49,0 & 3,60 & 20,0 & 4,14 & 112,2 \\
\hline 21,0 & - & - & 6,79 & 114,4 & - & - & 3,26 & 28,4 & 5,2 & 47,0 & 4,20 & 28,0 & 3,63 & 63,1 \\
\hline 22,5 & - & - & 5,55 & 162,0 & - & - & 3,42 & 29,4 & 5,4 & 52,0 & 4,80 & 35,0 & 4,65 & 86,5 \\
\hline 24,0 & - & - & 8,08 & 170,1 & - & - & 3,75 & 30,2 & 5,5 & 52,0 & 4,90 & 36,0 & 4,65 & 87,8 \\
\hline 25,5 & - & - & 8,49 & 201,2 & - & - & 3,91 & 32,8 & 6,0 & 52,0 & 5,00 & 36,0 & 3,61 & 19,5 \\
\hline 27,0 & - & - & 7,49 & 111,5 & - & - & 4,07 & 34,6 & 5,4 & 51,0 & 5,10 & 45,0 & - & - \\
\hline 28,5 & - & - & 7,14 & 106,9 & - & - & 4,23 & 38,4 & 6,0 & 47,0 & 5,20 & 46,0 & - & - \\
\hline 30,0 & - & - & - & - & - & - & 3,88 & 39,2 & 5,3 & 52,0 & 5,30 & 47,0 & - & - \\
\hline 31,5 & - & - & - & - & - & - & 3,53 & 38,4 & - & - & - & - & - & - \\
\hline 33,0 & - & - & - & - & - & - & 3,86 & 41,3 & - & - & - & - & - & - \\
\hline 34,5 & - & - & - & - & - & - & 4,87 & 44,8 & - & - & - & - & - & - \\
\hline 36,0 & - & - & - & - & - & - & 4,18 & 43,8 & - & - & - & - & - & - \\
\hline 37,5 & - & - & - & - & - & - & 3,48 & 38,9 & - & - & - & - & - & - \\
\hline 39,0 & - & - & - & - & - & - & 4,49 & 40,2 & - & - & - & - & - & - \\
\hline 40,5 & - & - & - & - & - & - & 4,48 & 42,9 & - & - & - & - & - & - \\
\hline 42,0 & - & - & - & - & - & - & 4,82 & 44,6 & - & - & - & - & - & - \\
\hline 43,5 & - & - & - & - & - & - & 5,15 & 48,6 & - & - & - & - & - & - \\
\hline 45,0 & - & - & - & - & - & - & 4,80 & 50,2 & - & - & - & - & - & - \\
\hline 46,5 & - & - & - & - & - & - & 4,96 & 52,4 & - & - & - & - & - & - \\
\hline 48,0 & - & - & - & - & - & - & 5,80 & 86,2 & - & - & - & - & - & - \\
\hline 49,5 & - & - & - & - & - & - & 6,37 & 105,4 & - & - & - & - & - & - \\
\hline
\end{tabular}

Table 5. Measured EM and pl characteristic

The measured pressure gauge values are mostly within the range of overconsolidated soils (Segelm, 1998), except for the two boreholes carried out in the localities of Ouled Moussa and Souk Sebt Ouled Nemma, which give 
relatively low measurements, relating to alluvial and sandy soils. As these localities are irrigated perimeters, this distinction is due to the presence of the two localities in formations dating from the middle Pleistocene (Service géologique du Maroc, 1985), characterized by channeled conglomerate deposits (Piqué et al., 2015).

Thus and in the light of the measurements and tests carried out, the geotechnical results obtained are in line with the bibliographical studies of the region studied (Beaudet, 1976 ; Choubert\& Faure-Muret, 1962 ; Michard, 1976 ; Piqué et al., 2015 ; Missante, 1963 ; Massoni et al., 1967) and are in agreement with the various findings raised by these studies, which makes it possible to validate the geological models of the studied zone.

In addition,the geotechnical measurementsaresupplemented with data relating to the bearing capacity of the Beni Moussa soils, proving a good bearing capacity (mainly within the over-consolidated soilsrange).

\section{Conclusion}

Through the lithological sections of seven core drill holes carried out in the Beni Moussa perimeter, the alternating formations and facies identified to be retained converge towards the results of previous bibliographical studies, mainly representing a succession of alluvial, clayey and silty deposits, deposited on calcareous formations. These results conform to the pressure parameters measured by means of a Menard pressure meter, which make it possible to distinguish between a zone with over-consolidated formations, representing the majority of the perimeter, and another with formations of less than average bearing capacity, dating from the middle Pleistocene.

The data from the present study generally reflect a good bearing capacity of the soil in the Beni Moussa zone, which is thus likely to support the superstructures that will be founded there due to its over-consolidated nature. However, it would always be advisable to carry out an in-depth geotechnical study of the soil for each project, especially since these studies have a probabilistic aspect and are based on core drillings which, after their analysis, will make it possible to generalize the mechanical and geotechnical characteristics of the soil.

\section{Acknowledgements}

We would like to thank the services of the Provincial Directorate of Equipment, Transport, Logistics and Water for facilitating our access to the sites that are the object of this study and for their support during data collection. 


\section{References:}

1. Association Française de Normalisation. (2015). Reconnaissance et essaisgéotechniques - Essaisen place - Partie4 :essai au pressiomètreMénard. Paris La Défense : AFNOR.

2. Beaudet, G., Maurer, G., \&Ruellan, A. (1967). Le quaternaireMarocain - Observations et hypothèsesnouvelles. Revue de géographie physique et de géologiedynamique (2), volume IX, fascicule 4, 369-310.

3. Choubert, G., \&Salvan, H. M. (1976).Évolution du domaineatlasiquemarocaindepuis les temps paléozoïques. Mémoires de la Société géologique de France, 447-527.

4. Etienne, H. \&Guessab, D. (1975).RessourcesenEau du Maroc - Tome 2 - Plaines et bassins du Maroc atlantique. Rabat : Éditions du Service Géologique du Maroc.

5. Massoni, C., Missante, G., Beaudet, G., Combes, M., Etienne, H. P., \& Ionesco, T. (1967). La plaine du Tadla. Les cahiers de la recherche agronomique, 24, 163-194.

6. Michard, A. (1976).Éléments de GéologieMarocaine. Rabat : Éditions du Service Géologique du Maroc.

7. Missante, G. (1963). Les sols du Tadla et leurrépartitionschématique au 1/500 000e.Revue AL AWAMIA(Maroc), 9, 155-190.

8. Piqué, A., Soulaimani, A, Laville, E., Amrhar, M., Bouabdelli, M., Hoepffner, C., \&Chalouan, A. (2015).Géologie du Maroc. Retrieved fromhttps://www.researchgate.net/publication/280485412

9. Segelm, A. (1998).Notice générale D60 version 1998 - Règles de réalisation des essais au pressiomètreMénard et d'exploitation des résultatsobtenus pour le dimensionnement des fondations. Retrieved from http://www.apageo.com

10. Service géologique du Maroc. (1985). Carte géologique du Maroc (1/1.000.000). Rabat : Éditions du Service Géologique du Maroc.

11. Taibi, A. N., El Khalki, Y., \& El Hannani, M. (2015).Atlas régionalrégion du TadlaAzilal Maroc. Retrieved from http://okina.univ-angers.fr/publications/ua9275. 